\title{
MELODIC DETERMINANTS IN TONAL STRUCTURES
}

\section{Frits R. Noske (Amsterdam)}

The growing concern of present-day musical research with the methodological aspects of analysis involves serious criticism of traditional analytical procedures. Objections have been raised, for example, against the lack of explicitness with regard to chosen concepts and methods, the constant mixing of different semiotic levels, and the treatment of the musical analysandum as a measurable object instead of a process determined by factors.

Unlike these targets of criticism, certain aprioristic notions used in traditional analysis have received little attention. The present paper deals with one of these assumptions, namely that the structure of $a$ tonal composition is exclusively governed by the laws of functional harmony. In other words, a chordal progression is considered explainable only in terms of tonic, dominant or subdominant functions within a given key. Even in the case of a modulation, where a chord may occur in two different keys, the functional framework remains the structural determinant: the centrifugal force of a function in the former key is taken over by the centripetal force of a function in the new one.

To contravert this unspoken doctrine is anything but difficult. Consider, for example, the following passage from the 'chair' terzetto of Le nozze di Figaro (Act I, no. 7, bars 16-27):

Example 1

(16)

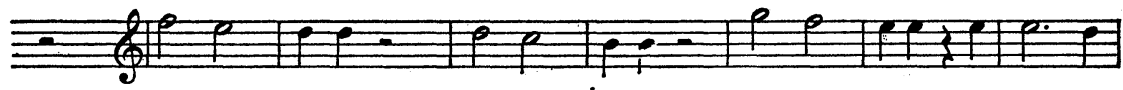

In mal pun-to son qui giunto, per-do - na-te, o mio Si-

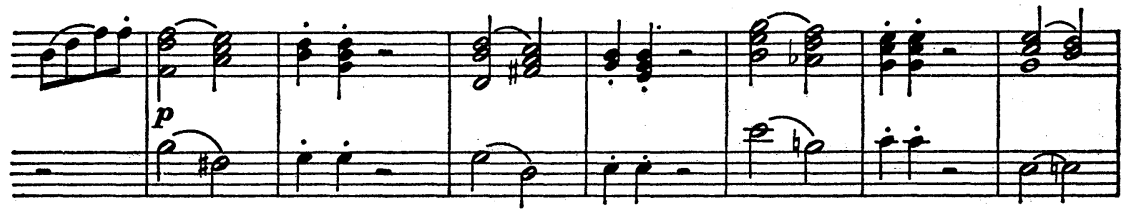




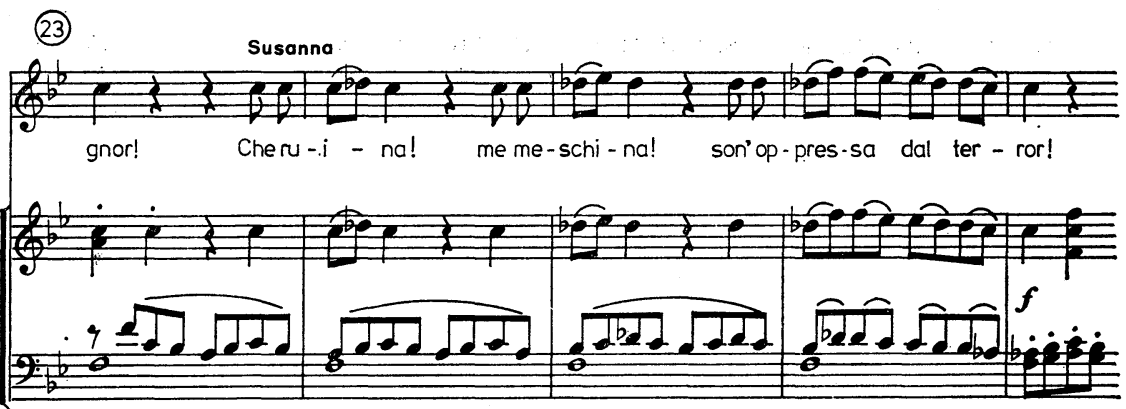

The key is Bb and Basilio's accompaniment passing through the sixth, fourth and second steps leads to the dominant, the harmony which supports Susanna's ensuing exclamations. Yet in bar 27 we become aware of having landed in the realm of $\mathrm{F}$ minor, the key which, though half-way changed into its major variant, will be maintained as far as bar 65. What has happened? And exactly when did it happen? The traditional analyst will point out that through the diminution of its third the dominant of $\mathrm{Bb}$ has been turned into the tonic chord of $\mathrm{F}$ minor. However, it is doubtful whether the listener will perceive the passage in the same way. Mozart's procedure seems most unusual: a new key is established on an unchanged bass. Using my ears and defying the "rules" of classical harmony I cannot but reinterpret the key of Susanna's initial phrase (b. 23-27) as F instead of Bb.

Although aural perception carries more weight than reasoning, arguments supporting this unorthodox interpretation should not be left unmentioned. From a dramatic point of view the fragment covering bars $23-65$ is an entity. It contains several interrelated actions: Susanna's expression of despair, her faked swoon, and her "awakening" at the moment that Basilio mentions the chair. This dramatic framework is matched by Mozart's treatment of rhythm and melody. The uninterrupted quaver movement of the violins starting at bar 23 ends precisely at bar 65. Moreover Susanna's initial motifs ("Che ruina! me meschina!') reappear at the end of the fragment in the orchestra (b. 57-59 and 61-63). Thus we are dealing with a musical as well as a dramatic unit, and this makes the assumption of the entire section being written in the key of $F$ the more plausible.

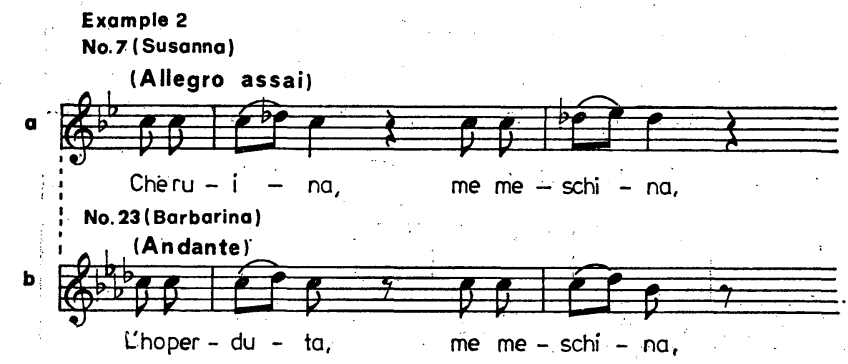


Another argument may be derived from a comparison of Susanna's initial phrase with that of Barbarina's cavatina (Act IV; cf. Ex. 2).

Elsewhere I have discussed the general dramatic implications of the relationship between these two melodies. ${ }^{1}$ Here it may suffice to point out that both females are in trouble. Barbarina's phrase is in F minor and the least we can say of Susanna's is that it is sung on the same pitch. Taking in consideration Mozart's sensitivity for keys related to specific dramatic concepts, Susanna's harmony seems to point to the key of $\mathrm{F}$ rather than $\mathrm{Bb}$.

Whatever the correct interpretation of the ambivalent procedure in bars 23-27 may be, one thing is beyond doubt: it will always be at variance with the doctrine of tonal structures being exclusively determined by the interaction of harmonic functions. The question of whether in this passage melody as a determining structural factor prevails over'harmony must be left open. In other instances, however, there can be hardly any doubt about the prevalence of the melodic parameter with regard to structure. I will try to show this by analysing various fragments taken from Verdi and Wagner. ${ }^{2}$

The slow section of the Overture to Verdi's French opera, Les vépres siciliennes, includes the following passage:
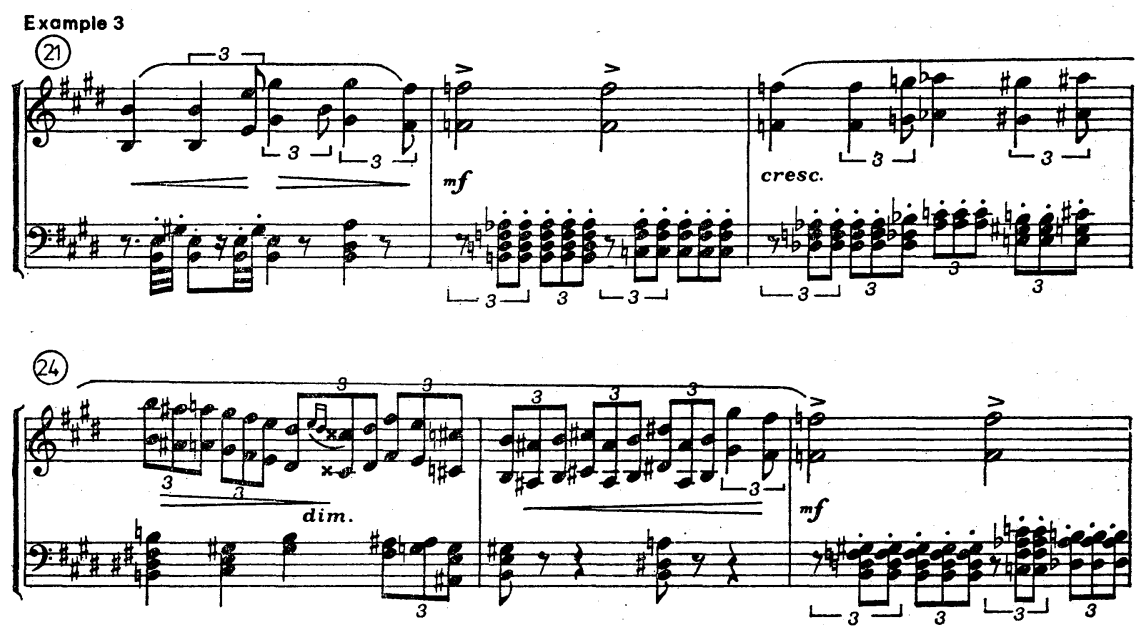

1 See F. Noske, The Signifier and the Signified: Studies in the Operas of Mozart and Verdi, The Hague 1977, p. 30.

2 The fact that all examples discussed are taken from operatic scores is not significant. The present article is a by-product from my studies in musical drama and therefore confined to works belonging to this genre. There is every reason to assume that similar examples can be found in the realm of instrumental music. 


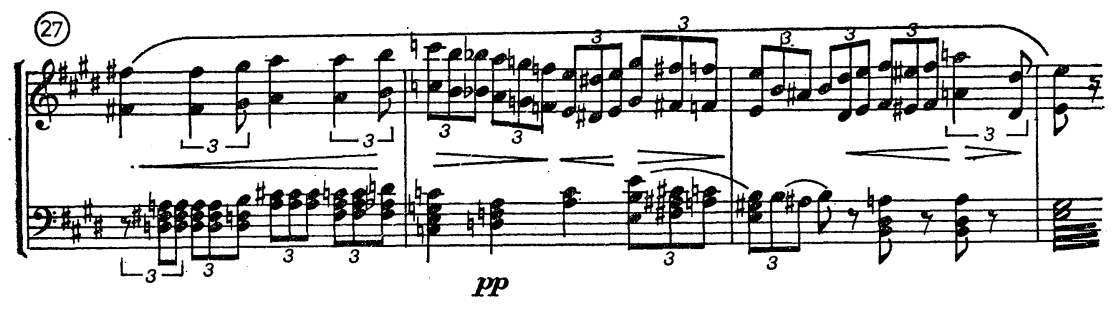

These nine bars contain an extensive elaboration of Hélène's aria, "Viens à nous, Dieu tutélaire!" (Act I). The extension starting with a deceptive cadence in bar 22 considerably stretches the limits of the key of $\mathrm{E}$ major, but in bar 24 we are back on familiar ground and what follows is a regular cadence. Despite the detour there has been no question of a modulation and, although the chordal progression in bars 22 and 23 is rather unorthodox, it cannot be called truly exceptional. Bar 26 starts with what seems to be a literal repeat of 22 , but on the fourth beat the chromatically ascending bass is accelerated involving a dominant seventh chord on $\mathrm{Db}(\mathrm{C} \#)$. As a result of this the passage now proceeds a semitone higher than before and one wonders how Verdi will succeed to reach the tonic haven of $\mathrm{E}$ major again. What happens is this: on the last beat of bar 28 a surprising succession of a minor triad on $E$, a major one on $F \#$ and a major sixth chord on $A$ leads back to the corresponding harmony of bar 25. Any attempt to explain this chordal progression in terms of functional harmony produces unacceptable results. It is true that, abstracted from their context, the relationships are interpretable in pairs; the last two chords, for example, are easily understood as a connection of a subdominant (Neapolitan sixth chord) with a dominant. As a whole, however, the succession defies functional interpretation, and therefore its structural determinant must be looked for outside the realm of harmony. A close examination of the fragment clearly points to the chromatic melody covering a descending minor third $(G \rightarrow E)$ which is located as a structural factor by its derivation from the beginning of both bars $24(\mathrm{~B} \rightarrow \mathrm{G} \#)$ and $28(\mathrm{C} \rightarrow \mathrm{A})$. So in this instance it is melody instead of harmony which determines the musical progression.

The soprano's strophic song in Act IV of the same opera ("Ami!... le coeur d'Hélène/pardonne au repentir") shows how close Verdi could come to the typically French tradition. The piece is a genuine romance whose graceful melodic line is supported by simple harmonies. ${ }^{3}$ Nothing induces us to expect the following astonishing passage in the song's closing cadence:

${ }^{3}$ In the original libretto the piece is called Romance indeed. Embedded in the great duet of Hélène and Henri it is followed by the cabaletta. 

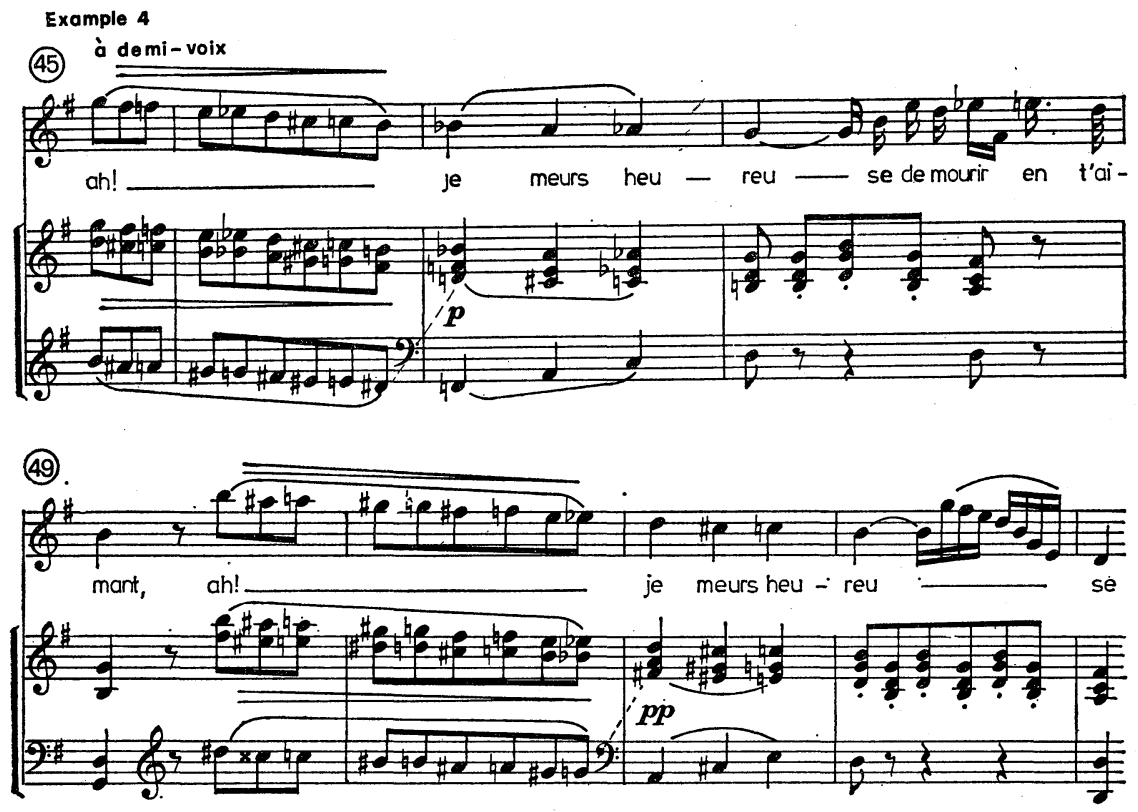

After four measures the passage is repeated two steps higher in the same key. Normally this would involve a change of chords, for instance, a minor triad instead of a major. Yet the harmony is transposed without the slightest change in the composition of the separate chords, and this provides additional evidence for its independency from tonal functions. The transposed repeat may appear less satisfactory than the passage's first occurrence. (Obviously Verdi wanted the tension to be raised and therefore he took the parallel octaves between the last chord of bar 51 and the first of bar 52 into the bargain.) Still this aesthetic consideration does not invalidate our observations on the independency of the bass. On the contrary, one might plausibly argue that it is precisely this independency which justifies the "forbidden" connection.

Let us now pass to the most famous battleground of harmonic analysis: the so-called Tristan chord.

Example 5

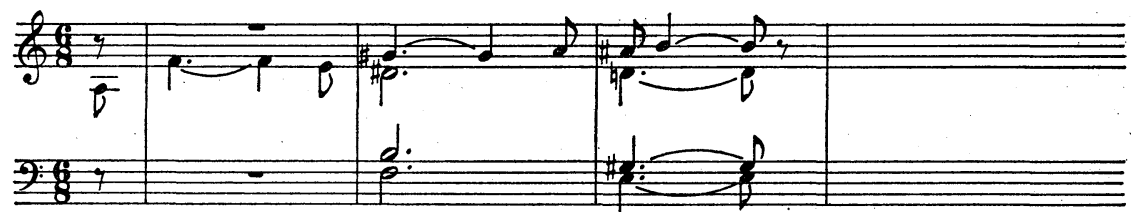


Since the last decades of the nineteenth century the chord $F-B$ $-D \#-G \#$ has been the object of divergent explanations. The list of its (mostly German) exegetists includes the names of Mayberger (1882), Jadassohn (1889), Arend (1901), Capellen (1902), Riemann (1909), Schoenberg (1911), Kurth (1920), Lorenz (1926), Erpf (1927), Schering (1935), Hindemith (1937), Distler (1940), Karsten (1951), Réti (1951), Keller (1958) and Vogel (1962). ${ }^{4}$ The great majority of these theorists, who searched for a functional explanation, can be divided roughly into two groups: the adherents of the dominant- and those of the subdominant function. Very little attention was paid in this endless but unprofitable debate to the melodic aspect of the three initial bars. Only Rudolph Réti seems to have been aware of its structural importance. Preoccupied as he was with "the thematic process", he convincingly showed the meaningful relationships between the beginning of the Prelude and the end of the opera, the Love-Death scene.

I am not concerned here with the tonal function of the Tristan chord, since I fully agree with Réti's view that "in accepted theoretical, that is, harmonic terms, this chord cannot be explained". ${ }^{5}$ The issue at stake is to establish the structural determinant of the Prelude's initial bars, a determinant which, I believe, can only be found by means of a melodic analysis.

Apart from the "upbeat" A the melodic material exclusively consists of a chromatic unit and its derivates. This unit is exposed in descending movement, first by the violoncellos and then continued by the cor anglais. In the second bar the oboe answers with the same fournote motif, this time however in ascending motion. Although in the beginning the two overlapping melodies share the same rhythm (b. 1-2), the third note of the ascending variant $(A \#)$ is considerably shortened, causing a "stretto" as the result of which both parts end simultaneously.

${ }^{4}$ R. Mayerberger, Die Harmonik Richard Wagners, Chemnitz 1882; M. Arend, Harmonische Analyse des Tristan-Vorspiels, Bayreuther Blätter 24, 1901, p $160 \mathrm{ff}$; G. Capellen, Harmonik und Melodik bei Richard Wagner, Bayreuther Blätter 25, 1902, p. 3 ff.; H. Riemann, Musiklexikon, 7th ed. 1909, entry »Klangschlüssel«; A. Schoenberg, Harmonielehre, Wien 1911, English ed., New York 1947; E. Kurth, Romantische Harmonie und ihre Krise in Wagners "Tristan", Bern-Leipzig 1920; A. Lorenz, Der musikalische Aufbau von Richard Wagners Tristan und Isolde, Berlin 1926; H. Erpf, Studien zur Harmonie- und Klangtechnik der neueren Musik, Leipzig 1927; A. Schering, Musikalische Symbolkunde, Jahrbuch Peters XLII, 1935, p. 23ff.; P. Hindemith, Unterweisung im Tonsatz, Part 1, Mainz 1937, English ed., London 1942; H. Distler, Funktionelle Harmonielehre, Kassel-Basel 1940; W. Karsten, Harmonische Analyse des Tristanakkordes, Schweitzerische Musikzeitung 91, 1951, p. 295ff.; R. Réti, The Thematic Process in Music, New York 1951; W. Keller, Tonsatzanalytik, Regensburg 1958; M. Vogel, Der Tristan-Akkord und die Krise der modernen Harmonielehre, Düsseldorf 1962.

I am indebted to Professor Jan van der Veen of Leyden University, who kindly provided me with these bibliographical data.

5 Réti, op. cit., p. 337. 
What we have heard is a rhythmically irregular canon in motu contrario and, as will be explained below, this contrary movement has a specific dramatic meaning.

The lower parts are clearly derived from this material. Functioning as a bass the second bassoon repeats the initial descending interval $(\mathrm{F}-\mathrm{E})$, while the first bassoon "summarizes" the compass of the ascending melody $(G \# \rightarrow B)$ in retrograde motion (B-G\#). Thus the entire fragment is structurally determined by a chromatic progression covering a minor third. The notes of the Tristan chord should therefore not be taken as a chord in a tonal, that is, a fuctional sense, but merely as simultaneously sounding components of melodic lines.

The three initial bars of the Prelude are generally referred to as: a "leitmotiv". In point of fact it concerns two versions of a motif, expressing two different dramatic ideas. ${ }^{6}$ One, the descending chromatic melody, is a classical topos designating the concept of sorrow. Although it does not cover the traditional interval of a fourth, it is related to innumerable examples occurring in the works of earlier composers. and reaching back as far as Dowland's Lachrimae. ${ }^{7}$ The ascending melody, on the other hand, is to be considered a true "leitmotiv" in so far that its meaning ("desire") exclusively belongs to this particular drama. ${ }^{8}$ It is conspicuous that the contrary motion of both versions exactly reflects opposing characteristics of the two concepts of sorrow and desire. The first has a distinct cause but nobody knows when and where it will end; the second has an indefinite origin but aims at something specific. In other words, "sorrow" refers to the past, "desire" to the future. The musical structure answers this dramatic antithesis in a most meaningful way.

My second example illustrating the structural role of the melodic parameter in Wagner's operas is taken from the final scene of Die Walküre. It concerns the so-called "leitmotiv" of Brünnhilde's magic sleep.

6 This particular point was already mentioned by Ernest Newman (The Wagner Operas, New York 1963, p. 207). Curiously enough Newman does not include the notes $\mathrm{D} \#$ and $\mathrm{D}$ in the descending «sorrow" variant. Obviously he was not aware of the fact that the two versions of the motif overlap.

7 Elsewhere in Tristan und Isolde Wagner does use the topos in its traditional form, that is, as a descending chromatic melody covering a fourth. See, for instance, the "Tantris" motif in Act I, Sc. 3 (Isolde: "Darinnen krank ein siecher Mann"), which also includes the upbeat of a sixth filled up with quaver triplets. Another example is found later in the same scene: the orchestral motif preceding Brangäne's words: „O Wunder! Wo hatt' ich die Augen?"

8 See C. Dahlhaus, Zur Geschichte der Leitmotivik bei Richard Wagner in Das Drama Richard Wagners als musikalisches Kunstwerk, Regensburg 1970 , p. $33-34$. 


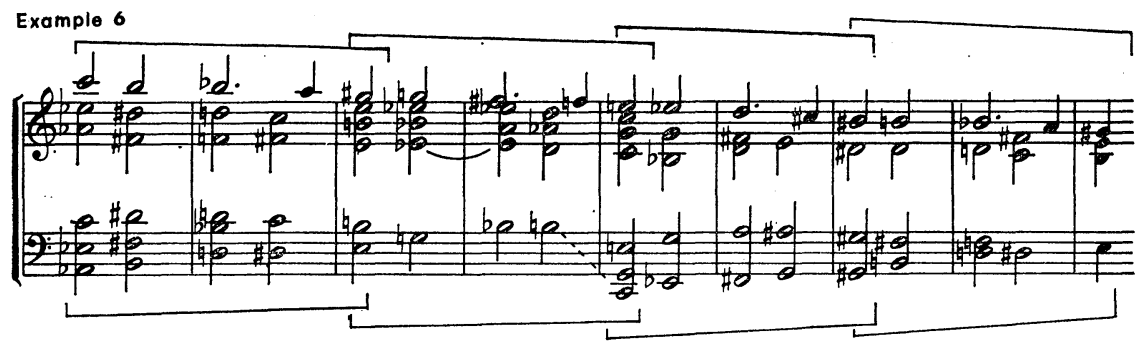

At first sight it looks as if certain groups of chords abstracted from this passage would lend themselves to functional interpretation within a specific key. For instance, the succession of $\mathrm{D}-\mathrm{F}-\mathrm{Bb}$, $\mathrm{D} \#-\mathrm{F} \#-\mathrm{A}-\mathrm{C}$ and $\mathrm{E}-\mathrm{G} \#-\mathrm{B}$ in the second and third bars seem to point to a half-cadence in A minor. On reflection, however, it becomes clear that this does not help in the least to construe tonal relationships. Even if we take the triads on the strong beats of bars $1,3,5,7$ and 9 as indicators of keys, then the question of whether it concerns tonic or dominant chords remains unsettled. As a whole the chordal chain defies functional explanation, the more so because two chords in bars 3 and 4 disturb the overall symmetry. And if we take a look at the frequent quotations of this "leitmotiv" in Siegfried and Götterdämmerung we come acros other variants (for example, the second and third chords as augmented triads). ${ }^{9}$ In all these cases both the upper part and the bass remain unimpaired and this points to the outer voices, rather than the chordal succession, being the determinant of the overall structure.

Melodically the fragment is constructed in a most regular way. It consists of four equal overlapping sections, the first two of which are orchestrated for woodwinds, the latter two for strings. Another feature of consequence is the arithmetical proportion between the compass of the upper part and that of the bass, which is exactly one to two (in each section the 'treble' covers a major third and the bass an augmented fifth). Moreover these outer parts share a characteristic which

\section{Example 7}

$\therefore$ e bo
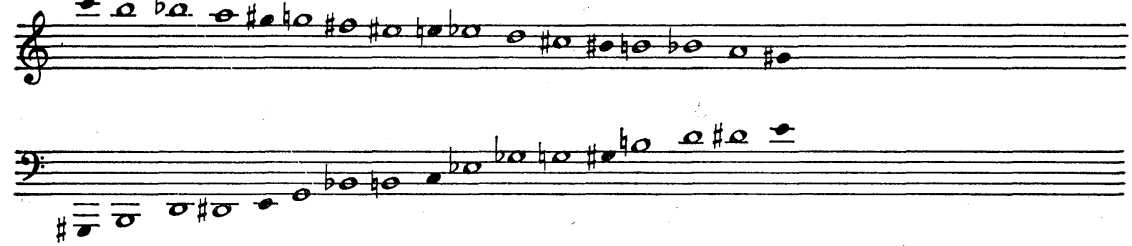

seems to me of major importance: both are exclusively composed of dividers of the octave (minor seconds and minor thirds). As a result of

${ }^{9}$ Siegfried, Act III, Sc. 1, passim. 
this the two patterns cannot function as factors of tension around a tonal center. (The same holds for compositions built on other octave dividers, like Debussy's piano prelude Voiles, which makes use exclusively of whole tones). Of course this lack of functionalism does not imply that the fragment in question is devoid of melo-harmonic tension, but merely that in this case the interplay of stress and relaxation develops quite independently from tonal functions. The true cause of this independency does not lie in the separate configurations of uppervoice and bass patterns but in the combination of both. Used separately they can very well operate as bearers of tonal functions, as is witnessed by a passage in the Prelude to Götterdämmerung. Here Wagner ingeniously joins the inverted bass pattern of the Magic Sleep with the melody of the Death Annunciation.

Example 8

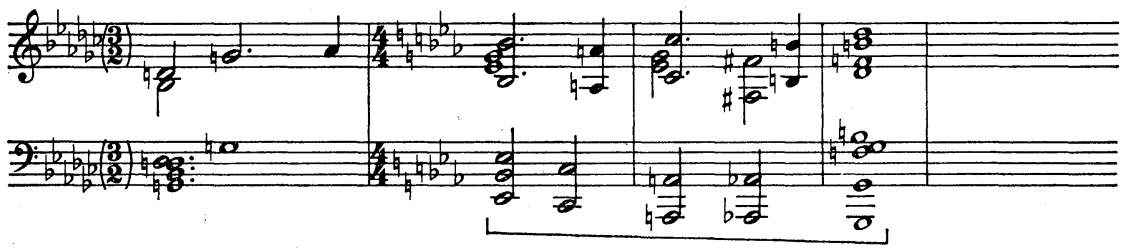

In the above-discussed examples from the Overture and Act IV of Les vêpres siciliennes (ex. 3 and 4 ) the predominant melodic material is also built on an octave divider (the semitone), and the same holds for the initial bars of the Tristan Prelude (ex. 5). But only the Walküre fragment exposes a mathematical elaboration of this principle enabling us to explain the 'divorce' of structure from tonal functions.

The quality of a single tone naturally depends on its physical properties, such as pitch, duration, timbre and intensity. On the ground of this indisputable fact one may reasonably postulate that these parameters also function as constituents for a synchronic or diachronic combination of tones, that is, a structure. Although in various musical systems certain parameters may play a more determining role than in others, there is no justification for assuming harmony to occupy a privileged place in the hierarchy of structural constituents. Yet this premise is nearly always implied in traditional analysis of tonal music. The question arises: What might be the reason for the sharing of an apparently false assumption by so many analysts?

To answer this question is not at all easy, because of the lack of explicit principles, inherent in traditional analytical procedures. Still I venture to offer the following explanation.

The answer must not be looked for in the analysed object but in the traditional teaching of music theory. From time out of mind con- 
servatories and music schools all over the world have taught their students the rules of harmony, that is, a closed system of combining chords, which for didactic purposes is artificially detached from other more or less rigid systems, like that of counterpoint. As far as I am aware it was Charles-Simon Catel who published the first practical schoolbook of harmony in 1802.10 This book was significantly written as a teaching aid for the recently founded Paris Conservatory, which soon after became the model for similar institutions in various European countries. One might wonder how Mozart, Haydn, Gluck and their contemporaries, none of whom had such a book at his disposal, ever succeeded in mastering the craft of harmony. Obviously they did, and very probably they obtained their craftmanship in a much more natural way than the pupils of nineteenth-century conservatories. Their teachers made them study the simultaneous handling of all music parameters in order to arrive at a stage where they could write good musical setting. While it is true that during the nineteenth century the study of harmony offered a direct way to musical composition, this does not hold for the situation of our time. Still, if the knowledge of classical harmony is of little use for the creation of today's music, it can be applied to the analysis of works from the past. It is here that the lack of the study of melody recoils upon the analyst. He has never been taught a Melodielehre comparable to the harmonic system codified by Catel and his successors. As a result of this, too many musical phenomena, procedures and devices are interpreted exclusively in terms of harmony.

One example may suffice to show this. It is wrong to speak as is usually done - of both the concepts of cadence and sequence as harmonic devices. As to the former, there may be no disagreement about its harmonic implications; the latter's nature, however, is primarily melodic. The progression of a diatonic, non-modulating sequence conditions its underlying harmonies to such an extent that even an otherwise forbidden chord, the diminished triad on the seventh degree of the tonal scale, cannot be avoided.

The melodic parameter is a much-neglected component in musical analysis. It is true that analysts do speak of melody fairly often, but nearly always in terms of musical form. Analysis of form, which usually amounts to little more than sectional description, merely touches the surface of the musical object. If we want to analyse the underlying structure, we will have to think of a process in which various factors contribute to bring the music into being. There is no reason whatever to justify the assumption that in this process melody would play a less determining role than harmony.

10 Traité d'harmonie, Paris 1802. In spite of the homonymous title this book differs as a treatise from that of Rameau. It does not add anything to the latter's ideas but merely shapes them into a didactic form. 


\section{POVZETEK}

Avtor razprave izraža dvom glede resničnosti prikrite doktrine, ki jo najdemo $\mathrm{v}$ tradicionalnih analizah tonalne glasbe, namreč, da obvladujejo strukturo kompozicije izključno zakoni funkcionalne harmonije. Primer iz Mozartove »Figarove svatbe« (tercet $s$ stolom) pokaže, da je lahko včasih tonaliteta nekega pasusa nejasna, ker nam harmonske funkcije ne dajo potrebne opore (gre za navidezno modulacijo na nespremenjenem basu). Drugi primeri, ki so vzeti iz Verdijeve francoske opere "Les vêpres siciliennes«, pa so kljub uporabi »normalnih" akordov funkcionalno nerazložljivi. Tu le melodični parameter določa strukturo teh fragmentov. V nasprotju $z$ neštetimi in obenem dokaj brezplodnimi poskusi, da se harmonsko analizira začetne takte predigre $\mathrm{k}$ »Tristanu in Izoldi«, opredeljujejo tokrat strukturo $\mathrm{v}$ čisto glasbenem in dramatskem smislu melodične linije. Glede prvega se zdi, da predstavlja kromatična linija, obsegajoča interval male terce in podana kot ritmično iregularen kanon in motu contrario, gradivo celotnega fragmenta (tudi spremljujoči parti izhajajo iz nje). Glede drugega pa je treba ugotoviti, da simbolizira nasprotno oziroma retrogradno gibanje kromatičnih linij bistvo celotne glasbene drame: te linije predstavljajo nasprotne pojme »žalosti« (glede na preteklost) in »hrepenenja (glede na prihodnost). Končno daje motiv Brünnhildinega čarobnega spanja (Valkira, 3. dej.) primer matematičnega razmerja med zgornjim glasom in basom, ki se oba poslužujeta »delitelja« oktave (male sekunde in male terce). V nasprotju z akordi, ki so tonalno nerazložljivi, ti dve melodični liniji skupno določata strukturo.

Zakaj so analitiki tonalne glasbe tako dolgo zanemarjali melodični parameter? Odgovor ne najdemo $v$ glasbeni teoriji, ampak kratkomalo $v$ glasbeni vzgoji. Imamo pač nauk o harmoniji, ki umetno deli akorde in njihove postope od drugih bistvenih glasbenih elementov. Seveda pa še nimamo ničesar, kar bi bilo sprejeto kot nauk o melodiji. Odtod nadvlada harmonije $\mathrm{v}$ tradicionalnih analizah. Analiza, ki bi hotela preseči goli opis, bi zato morala upoštevati vse glasbene parametre. 